\title{
Compensation and cost of conservation payments for biodiversity
}

\author{
by \\ Bart Minten $^{1}$ \\ Cornell University
}

May 2003

Slash-and-burn agriculture in poor tropical countries is one of the main causes of deforestation, leading to environmental costs and to potential externality effects on lowland agricultural productivity. Under innovative environmental policies, direct conservation payments to farmers are starting to be implemented to induce them to abandon slash-and-burn agriculture as well as the use of forest resources altogether. However, appropriate compensation levels are often difficult to get at. Using a stochastic payment card format in a case study in Madagascar, it is estimated that farmers would abandon slash-and-burn agriculture and forest use for median annual compensation payments at a lower bound of around $85 \$$ and $177 \$$ per household respectively. As expected, the econometric analysis shows that there exists a systematic relation between poverty and the required compensation for forgone land use. While poorer households depend relatively more on forest products, they accept a lower amount to abandon slashand-burn agriculture and forest use. Better educated and older households require higher payments.

\footnotetext{
${ }^{1}$ Cornell Food and Nutrition Policy Program, Cornell University; Address: Ilo program, BP 6317, Antananarivo 101, Madagascar; e-mail: bminten@dts.mg. I would like to thank Jurg Brand, Tim Healy, Andy Keck, and Claude Randrianarisoa for help with the set-up of survey, helpful discussions and comments on preliminary results. The field work for this research was financed by ONE (Office National de l'Environnement), PAGE (Projet d'Appuie à la Gestion de l'Environnement) and by the Ilo program. The two last projects are financed by USAID-Madagascar. Any remaining errors are solely my responsibility.
} 


\section{Introduction}

In most developing countries, one of the major reasons for biodiversity loss due to human activities is slash-and-burn agriculture by local farmers (Barrett, 1999). In order to preserve biodiversity, governments often resort to setting aside land in protected areas. The establishment of these protected areas imposes costs on the agricultural households surrounding the area and lead often to conflicts if not done properly or if compensation mechanisms do not exist (Wells et al., 1990; Ghimire, 1994; Kramer et al., 1994). Improper relations often lead to unsustainability in management of the protected area as well as problems for sustainable resource use.

The loss of biodiversity contained in tropical forests is a cause of global concern. However, the current costs of preservation are often not off-set by user values through for example tourism and it seems that the costs are disproportionally borne by the people surrounding the area rich in biodiversity. While most people would acknowledge that the total economic benefits - taking into account non-use values (option, existence and bequest values) could easily compensate for the imposed costs - the issue of regional and intergenerational compensation remains to be tackled in a more satisfactory manner.

Recently, innovative policies using conservation contracts to contribute to biodiversity conservation have been put in place in different parts of the world (Pagiola et al., 2002; Ferraro, 2000). ${ }^{2}$ In this type of contracts, direct payments are given to resource managers for biodiversity conservation services through protection of biodiversity-rich sites. The benefits provided through the contract provide an incentive to the resource manager to maintain the resource, for example recompensing direct costs incurred to maintain the resource (e.g. surveillance) and opportunity costs from not exploiting the resource. While the advantages and disadvantages of this type of policy are still being debated (Swart,

\footnotetext{
2 They include for example Costa Rica Environmental Services Program, Zimbabwe's CAMPFIRE program, El Salvador Natural Resource Management Project, US's Conservation Reserve Program, Columbia's Carea valley and Madagascar's ANGAP's entry fees program.
} 
2003; Ferraro and Kiss, 2003), one important issue relates to appropriate compensation mechanisms for resource managers. ${ }^{3}$

Madagascar is a good case study to evaluate conservation payments for biodiversity given that some organizations are starting to practice it (Durbin, 2002) and given that the country is characterized by a high bio-diversity and a richness of endemic species. ${ }^{4}$ As the vast majority of Madagascar's exceptional biodiversity is concentrated in the less than $20 \%$ of the island that remains forested (Barrett, 1999), forest degradation and fragmentation due to human activities is considered the main threat to their unique biosystem (Jarosz, 1993; Keck et al., 1994). ${ }^{5}$

Through better insights in valuation of resources by the local population, planners might come up with more appropriate and cost efficient compensation levels to ensure sustainable resource use. A survey was therefore organized with farmers that practice slash-and-burn agriculture ("tavy") in the forest region of Northeastern Madagascar (Maroantsetra). A valuation questionnaire, using the contingent valuation technique through a stochastic payment card method (see Wang and Whittington, 2000), was implemented in order to estimate the benefits of slash-and-burn agriculture and forest use. This type of methodology is appropriate in conducting ex ante assessments of environmental interventions and could lead to a better targeting of mitigating efforts.

The contribution of this analysis is threefold. First, it proposes a simple and easy replicable methodology to estimate appropriate compensation level for agricultural households to abandon slash-and-burn agriculture and forest use. Second, it illustrates the

\footnotetext{
${ }^{3}$ Alternative policies have tried to develop an incentive system so that farmers would intensify on their existing land (and especially their lowland) while refraining from extensive agriculture in forest area. Compensation mechanism might include improved rice seeds, better infrastructure, etc.

${ }^{4}$ Madagascar has been recognized as one of the twelve megadiversity countries (McNeely et al., 1990). Madagascar's unique biodiversity stems from the fact that few plants and animals were present as the island split from Africa in the Gondwana supercontinent splitup. Over $80 \%$ of its plants, $95 \%$ of its reptiles, $99 \%$ of its amphibians, and close to $100 \%$ of its primates are found nowhere else in the world (White, 1983).

${ }^{5}$ This has been recognized by government and international agencies alike. Hence, Madagascar was one of the first countries to start with a National Environmental Action Plan and set aside significant amounts of forests in protected areas (Larson, 1994).
} 
effect of different determinants in natural resource valuation by rural households in selfsubsistence settings. Third, it shows the applicability of contingent valuation techniques in rural, little monetized, settings of developing countries where biodiversity rich sites are often found. The structure of the paper is as follows. First, the conceptual framework is presented. Second, the methodology and data are discussed. Third, the survey site, household characteristics and slash-and-burn practices are described. The analysis of the magnitude and econometric results of the valuation questions are presented in the next section. We finish with the conclusions.

\section{Conceptual Framework}

The implementation of conservation contracts for biodiversity leads to a reduction of the land available to the rural agricultural households surrounding the area. To motivate the econometric investigation, a model of an agricultural household can be specified as such:

$$
\begin{aligned}
& \operatorname{Max}_{L_{f}, L_{a}, L_{l}, L_{c}} U\left(X_{l}, X_{f}, X_{a}, X_{m}\right) \\
& \text { s.t } \\
& P_{a} X_{a}+P_{f} X_{f}+P_{m} X_{m} \leq Y \\
& Y=w L_{l}+P_{a} f\left(L_{a}, T_{a}+g\left(L_{c}, T_{f c}\right)\right)+P_{f} h\left(L_{f}, T_{f}\right)+I\left(T_{f}\right) \\
& L_{0} \geq L_{f}+L_{a}+L_{c}+L_{l} \\
& T_{0} \geq T_{a}+T_{f c}+T_{f} \\
& L_{f}, L_{a}, L_{c}, L_{l}, X_{a}, X_{f}, X_{m}, X_{l}, T_{a}, T_{f c}, T_{f} \geq 0
\end{aligned}
$$

Where: $\mathrm{X}_{\mathrm{a}}, \mathrm{X}_{\mathrm{f}}, \mathrm{X}_{\mathrm{l}}$, and $\mathrm{X}_{\mathrm{m}}$ are quantities of agricultural goods, forest goods, leisure and market goods respectively; $\mathrm{P}_{\mathrm{a}}, \mathrm{P}_{\mathrm{f}}, \mathrm{P}_{\mathrm{l}}$, and $\mathrm{P}_{\mathrm{m}}$ are prices of agricultural goods, forest goods, leisure and market goods respectively; $\mathrm{Y}$ is total endogenous income; $\mathrm{T}_{0}, \mathrm{~T}_{\mathrm{a}}, \mathrm{T}_{\mathrm{fc}}$, and $\mathrm{T}_{\mathrm{f}}$ are total area endowment, area devoted to agriculture, converted forest area, and area under forest respectively; $\mathrm{L}_{0}, \mathrm{~L}_{\mathrm{a}}, \mathrm{L}_{\mathrm{c}}, \mathrm{L}_{\mathrm{f}}$ and $\mathrm{L}_{1}$ total time endowment, labor allocated to agriculture, forest clearing, gathering of forest products, and leisure respectively. 
The maximization problem states that the household allocates time in such a way that it maximizes utility given an income constraint where income can be obtained from wage labor, agricultural activities, forest products, and exogenous income. Labor allocation is constrained through a time endowment and area use through an area endowment. It is assumed that the utility function is quasi-concave with respect to each argument $\mathrm{X}$. Agricultural production is strictly increasing in land and agricultural labor and concave in each. Additional land $\left(\mathrm{T}_{\mathrm{fc}}\right)$ can be brought into production through clearing uncultivated forest using just labor (i.e. slash-and-burn or "tavy") which translates into agricultural land by a monotone concave production technology for both land and labor. Forest can be used to collect products from. The quantity of products collected depends on the area under forests and the time allocated to it (in a concave and increasing manner). The household can also hire out its time at a parametric wage rate w. Finally, exogenous transfers (I) supplement other types of income.

Assuming an interior solution, first-order conditions and comparative statistics imply that a loss of forest area will lead to the following ${ }^{6}$ :

(i) Labor will be used in agriculture and collection in the remaining forests up to the point where its marginal return equals the village level wage rate. A loss of forest area would mean that more labor would be devoted to agricultural production on existing land, to collection of forest products on still accessible forested land, or to wage labor. Higher wages through growth in the rest of the economy (f.ex. created by tourists) would be associated with less agricultural and forest activities.

(ii) Higher initial endowments of land, in terms of land quality or irrigation that increase the marginal productivity of existing land, would lead to less demand for forested areas. This applies also to technical assistance to the degree that it allows farmers to increase the productivity of their preexisting land endowment rather than to expand production onto hithertho forested areas. To

\footnotetext{
${ }^{6}$ The problem can be solved explicitly if one assumes a specific functional form. To derive closed form solutions, one could use standard Cobb-Douglas agricultural production and forest production functions.
} 
the extent that policies could lead to a shift of existing production function, part of the income loss could be off-set.

(iii) Investment in land-intensification technologies will be undertaken only if the higher agricultural productivity ensures that the effect is sufficient to offset the associated loss in wages or forest income.

Hence, the likely effect of the reduction in available land can be summarized as follows: a) Loss in income from forest products due to loss of forest land; b) Loss in agricultural income due to loss in agricultural land; c) Adjustment to losses through increases in exogenous income and through labor re-allocation to land intensification or to off-farm labor. Given this is a land constrained solution, a contingent valuation question was formulated to try to evaluate the willingness-to-accept compensation of the rural households after land use losses. The willingness to accept (WTA) compensation for foregoing land use is the quantity of money which, if given to the individual after the loss of land, would leave him or her at the same level of utility as if no loss of land had occurred. This can be written in terms of the indirect utility function $v$ which describes the maximum utility achievable at given prices and income (Varian, 1992):

$$
v\left(\mathrm{P}, \mathrm{Y}_{1}\right)=v\left(\mathrm{P}, \mathrm{Y}_{0}+\mathrm{WTA}\right)
$$

where $Y_{0}$ and $Y_{1}$ is income with and without slash-and-burn agriculture respectively.

\section{Data and methodology}

The empirical analysis is based on primary data that were gathered in Madagascar in a collaborative effort between ONE (Office National de l'Environnement), the Ilo program of Cornell University, and the PAGE (Projet d'Appuie à la Gestion de l'Environnement) project run by the International Resources Group. A survey was organized in November 2001 with 120 farmers that practice slash-and-burn agriculture in northeastern Madagascar, in the area northwest of the city Maroantsetra. The farmers were randomly selected within a census of 52 watersheds. The area is renowned for its high and rather untouched forest resources. However, increasing population pressure leads people to encroach into the forest. 
The survey consisted of two parts. First, it collected data on demographic variables, income generating activities (agricultural and non-agricultural), slash-and-burn agriculture, and wealth (including land and livestock possession, buyer status of rice, length of lean period, and access to credit). This information allows us to have insights in the economic situation of rural agricultural households in the area. Then, two contingent valuation questions were asked similar to the one used by Shyamsundar and Kramer (1996). The valuation questions were formulated in the following way:

"Suppose that you are compensated in rice not to use the forest. In a first situation, you can transform the forest for agricultural production. In this case, you will obtain rice, maize or other agricultural production, but you will have lost the benefits of the existence of the forest. In a second situation, access to the forest will be limited: you will not be allowed to do slash-and-burn agriculture but you will be allowed to use forest products for wood, medicinal plants, hunting, ... The forest might also reduce flooding of ricefields in the lowlands. Are you willing to give up the practice of slash-and-burn agriculture for a compensation? (Yes/No) If yes, how much is the quantity of sobika of rice every year that you would need to give up slashand-burn agriculture?"

Instead of the widely used and recommended dichotomous choice valuation question (Arrow et al., 1993), a stochastic payment card method (Wang and Whittington, 2000) was implemented for different reasons: (1) Given logistical constraints, a relatively small sample had to be relied upon. The payment card format gives the benefit of having extra information beyond the yes/no question (For papers that discuss the benefits of information beyond dichomotous choices, see Blamey et al. (1999) and Ready et al. (2001)). (2) Whittington (1998) shows that a main problem in contingent valuation studies is that the range that is offered is often not large enough to allow for a robust estimation of the valuation function. Moreover, as we had little a priori knowledge about the valuation function, we had to make sure that extreme levels were included in the bids on the payment card. Given the small sample, this could not have been achieved in the dichotomous choice variable format. (3) Uncertainty (for example on the future price evolution of agricultural and wood products) and imperfect information (household chief had to answer immediately during the interview and could not consult with family members and/or village leaders) is allowed for in this format. 
The stochastic payment card system was set up as follows. First, an open-ended valuation question was asked on the amount of sobika of rice that they had to be offered 'for sure' to abandon slash-and-burn agriculture. A sobika is a local basket that contains about 12 $\mathrm{kgs}$ of rice. This type of value indication was preferred to local currency as the local economy is largely non-monetized. It was hoped that the open-ended question would reduce the starting point bias. Then, in follow-up questions, respondents were shown different levels on the payment card, ranging from 1 to 1000 sobika. References on the payment card were made to the value of locally traded goods such as a bicycle, radio, etc. For every level on the card, the interviewees had to respond to the proposition to abandon slash-and-burn agriculture with: 1. Accept to pay for sure; 2. A little bit in doubt but would say yes; 3 . Not yes or no, do not know; 4. A little bit in doubt but would say no; 5 . Will not pay for sure. In a second valuation question, respondents were asked to evaluate the same situation as the one described above but in this second scenario, farmers were not allowed to use any products of the forest anymore, i.e. they had to abandon forest use all together.

In the set-up of the stochastic payment card format, the Willingness to Accept (WTA) is manifested through a variable $\mathrm{I}_{\mathrm{i}}$ such that:

$$
\begin{gathered}
\mathrm{I}_{\mathrm{i}}=1 \text { if } \mathrm{WTA}_{\mathrm{i}}<\mathrm{t}_{\mathrm{i}} \text { and } \\
\mathrm{I}_{\mathrm{i}}=0 \text { if } \mathrm{t}_{\mathrm{i}} \leq \mathrm{WTA}_{\mathrm{i}}
\end{gathered}
$$

where $t_{i}$ is the bid offered to the household $i$. The overall valuation curve allows us to deduct median and mean WTA for the population as a whole. The probability of a response to a bid $t_{i}$ when the household has a vector of covariates $\mathrm{X}$ is given by:

$$
\operatorname{prob}\left(\mathrm{I}_{\mathrm{I}}=1 \mid \mathrm{X}\right)=\Phi\left(\mathrm{X}_{\mathrm{i}} \beta-\alpha \mathrm{t}_{\mathrm{i}}\right)
$$

where $\Phi$ denotes the cumulative standard normal distribution and $\beta$ and $\alpha$ are parameters. The vector of covariates used in the econometric analysis includes variables on household composition, background, wealth and use of upland agriculture.

\section{Description survey site and household activities}


The communities in the northeastern rain forests in Madagascar are rural and almost exclusively agricultural. Almost all of the households report that agriculture is their main profession. Average size of the household is six members (Table 1). Education levels are low: on average, the head of the household has only studied for a period of three years. $22 \%$ of the heads of households state they have never been to school. $8 \%$ of the households are female-headed and the average age of the head of household is 43 years.

Most of the households in the sample possess lowland as well as upland plots. The average area of both types of land is equal, around 73 ares. Hence, the households in the area do not depend exclusively on slash-and-burn agriculture for their income. In total, they own 1.5 ha of agricultural land, significantly above the national average (Randrianarisoa and Minten, 2001). On top, the average household reports to own almost 60 ares of savoka forest and 56 ares of primary forest. Other types of wealth include livestock. A household owns on average 1 zebu. However, livestock ownership is unevenly distributed as $70 \%$ of the households report not to own any livestock at all.

Total rice - the main staple - production per household was estimated to be around $910 \mathrm{~kg}$ last year, i.e. around $150 \mathrm{~kg}$ per capita. This amounts to average rice yields of 1.3 ton per hectare, significantly below the averages that were reported by the rice farmers in the lowlands (Brand et al., 2002). $76 \%$ of the households report that this rice production is not sufficient and that they have to buy rice during the lean period or rely on other food for subsistence. The reported length of the lean period, when households reduce consumption levels compared to the rest of the year, is estimated to be almost four months.

The composition of the monetary income of the households shows that income from rice is less important. Most of the rice that is produced is used towards own consumption. While overall monetary annual income is evaluated at 1.4 M Fmg (\$200) per household, income from rice is only $0.07 \mathrm{M} \mathrm{Fmg}$, i.e. less than $5 \%$ of the total. Income from tavy products makes up half of the monetary income of the households ( $0.7 \mathrm{M} \mathrm{Fmg).} \mathrm{While} \mathrm{the}$ total area of upland cultivated is equal to the area of lowland, the monetary income from 
production on uplands is significantly higher than for lowlands, indicating the presence of higher margin crops or more cash crops on the uplands than on lowlands.

Table 2 shows the importance of the different crops in the area. The importance of cash crops is striking. While rice and cassava are cultivated by almost all the household, a significant portion of them also report to produce cash crops such as vanilla, coffee, cloves, pineapple, or litchis. This importance of cash crops in livelihood is typical for the Eastern forest area in Madagascar. Monetary income from forest products is shown to be almost twice as high as for income from rice. Overall, quite some income diversification is noticed among these households.

In further analysis, the length of the lean period is used as an indication of the poverty level of the household (see Barrett and Dorosh, 1996). When poverty terciles are used to look at income composition, some revealing trends appear. Richer households have more lowland and upland and sell relatively more rice and tavy products. Poorer households rely relatively more on the sales of forest products. ${ }^{7}$ This seems to confirm the hypothesis of Freudenberger (1999) that it is the richer households that engage relatively more in tavy agriculture than the poorer ones. ${ }^{8}$

Table 2 further presents some statistics on tavy practices in the area. The importance of tavy in rice production is relatively minor. The stated reason for tavy production is mainly as a need to obtain food (58\%). Anecdotic evidence suggests that households often rely on tavy rice for their consumption in the lean period as the production period is different than the one for lowland rice. Only $18 \%$ of the households mention that they practice tavy for need of cash. When households were asked if they were willing to give up tavy for compensation, $93 \%$ agreed that they were willing to do so. For forest use, only $85 \%$ accepted. Hence, when conservation payments would be used, it seems that a small group of people would be unwilling to accept those and change their lifestyle

\footnotetext{
${ }^{7}$ Kerr (2002) presents similar findings in India: livelihoods of the landless poor often depend on gathering of products from the forest.

${ }^{8}$ Freudenberger (1999) looked at these issues in the area of Fianarantsoa. She mentions that the richer households do tavy to establish property rights on particular fields.
} 
accordingly. No major differences in socio-economic characteristics were detected for the protest respondents.

The previous section gives us a sense of the socio-economic situation of the households that live in the area. The agricultural and income statistics illustrate that setting land aside will clearly impose costs on the surrounding population given the importance of tavy and forest use for livelihood. In a next stage, it is tried to attach monetary values to the loss of forests or land as expressed by the household itself. To this, we now turn.

\section{Willingness-To-Accept analysis}

The results of the reported valuation to abandon slash-and-burn agriculture as well as forest use are shown in Figure 1. The graph shows the upper-bound level at which a specific proportion of farmers refuse ("do not accept for sure") to give up tavy and forest use. The median level of the upper bound at which tavy farmers would still refuse to give up tavy use is 32 sobika, i.e. around $380 \mathrm{kgs}$ of paddy rice and equivalent to $59 \$$. This indicates that if a vote would be held on that offer (or any lower offer for that matter) for the farming population as a whole, at least $50 \%$ of the population would refuse to accept. Table 3 indicates the results on the median and mean (area under the curve and calculated through linear approximation) for the refusal and the acceptance level to give up tavy use. The median acceptance level ("do accept for sure") is evaluated at 46 sobikas (=85\$). The mean is evaluated slightly higher, i.e. at $118 \$$. It is striking that the mean required compensation is close to the reported monetary income from tavy products, as reported in Table $1(119 \$) .{ }^{9}$ This might confirm the validity of the applied WTA format.

As expected, the valuation function for forest use is dominant over the whole domain to the tavy use valuation function. The median WTA to abandon forest use is evaluated at 96 sobika of paddy rice (177\$). The large difference between the tavy use and forest use numbers - higher than the actual income of forest products - might illustrate the

\footnotetext{
${ }^{9}$ These results are significantly below the estimates by Ferraro (1994) based on cash-flow analysis for the Ranomafana area and by Shyamsundar and Kramer (1996) based on similar contingent valuation question for the Mantadia park in Madagascar. This might be due to the higher poverty in the Maroantsetra area.
} 
substitution possibilities for remunerative activities of hillside agriculture by other activities. These substitution possibilities seem to exist less for forest products. The large difference might also indicate the non-monetary benefits of forest use as the difference is significantly larger than the monetary income out of forest use found in Table 1.

Figures 2 and 3 show the acceptance and refusal curve for tavy and forest use respectively, as well as the range of bids where the respondents expressed uncertainty. As expected, the number of farmers that were uncertain about accepting or refusing the offer is largest in the middle of the graph. For some bids, the uncertainty domain contains up to $15 \%$ of the farmers. This high number indicates the importance to allow farmers to convey information beyond the simple yes/no format as has been shown by other recent studies (Blamey et al., 1999; Ready et al., 2001).

Next, regressions were run to gain insights in the determinants of the valuation numbers. Four types of regressions were estimated. Dependent variables were compensation to give up tavy and forest use. For each of these variables, the minimum amount that they would be willing to accept for sure and the maximum amount that they would refuse for sure as compensation were used as monetary measures. Explanatory variables were household characteristics and land areas. It was assumed that a higher area in upland or in forest would lead to a higher demand for compensation.

The results of this contingent valuation regression are reported in Tables 4 and 5. The models have an explanatory power between $16 \%$ and $25 \%$ indicating that the elicited bids are non-randomly distributed. Age is shown to increase the compensation level for forest use. Older people might be less reluctant to accept the compensation as they usually have laid the biggest claim on forest land and they feel that they should be compensated the most. Moreover, older residents prefer to engage in tavy because it is less labor intensive and less strenuous as for example lowland rice paddy works (Ferraro, 1994).

Education is also shown to increase the required compensation level, for forest as well as tavy use. It might be that more educated households who have a higher reservation wage 
like to put more effort in off-farm earnings possibilities and hence, prefer to do agriculture in a more extensive manner. ${ }^{10}$ Hence, they would suffer more form the taking away of the land than the less educated. Other variables turn out not to be significant such as size of the household and gender of the head of household. While females seem to use different forest products than men, they do suffer equally from the loss of the forest use.

A significant determinant of the compensation level is the length of the lean period, an indicator of poverty in the area. This holds for forest as well as tavy use. Households that experience a lean period that is one month longer, are willing to reduce required compensation levels for tavy use by $8 \%$ and for forest use by $10 \%$. Richer households rely relatively more on tavy use than poorer households and will therefore ask more compensation. However, while poorer households use relatively more forest products, the lack of liquidity seems also to lead to their lower willingness to accept level.

Surprisingly, land area in possession variables are, overall, no major determinants of compensation levels. Households that possess more lowland are willing to accept less for compensation. It seems that these households are less dependent on tavy and forest for their livelihood and might be able to better live without it. However, the coefficients are not significant at conventional statistical levels. As expected, upland area is a significant determinant of WTA for tavy use but its coefficient is significantly less than one. This might be an indication that not all upland production is tavy production. Forest area in possession of the household is almost significant at the $10 \%$ level in the compensation level regression to abandon forest use. However, its coefficient is small, indicating that forest benefits do not increase proportionally with size. The overall low or insignificant coefficient might reflect the fact that forest products might not originate from private held land but from open access or community access regulated forests.

\footnotetext{
${ }^{10}$ Randrianarison (2003) shows, based on the national household survey of Madagascar of 2001, how the importance of off-farm income in rural areas in Madagascar increases significantly with education and income levels.
} 


\section{Conclusions}

The establishment of protected areas seems a straightforward way to sustain endangered forest resources rich in biodiversity. However, this is often not the case as shown by numerous conflicts between surrounding population and protected area management. Therefore it is useful to have insights in behavior of people that threaten the forests to ensure sustainability and manage conflicts. Recently, direct conservation payments for biodiversity have been put in place in different parts of the world. Insights in behavior of the surrounding population might lead to appropriate compensation mechanisms and therefore help to achieve sustainable management and resource use. This is studied in the case of Madagascar.

The results of the analysis of primary data show that the estimated median benefits of slash-and-burn agriculture ('tavy') and of forest use are $85 \$$ and $177 \$$ per household respectively. While lowland and upland are equally important in surface, tavy products makes up half of the income of the farmers in the sample indicating its relative importance for cash income. Monetary income from forest products is twice as high as income from rice products, indicating the high dependence on forest products for the livelihood of the local population. Poorer households use relatively more forest products. Regression results suggest that the imposed costs seem to differ non-randomly among households. Poorer households are willing to accept less while older and more educated households require more.

This research shows how valuation of natural resources can be done through the use of contingent valuation questions in high self-subsistence developing country setting. This type of questions leads to insights, could improve conservation efforts and could help in the setting of appropriate compensation levels for conservation payments for biodiversity. However, as the analysis focuses solely on the "victims" of the setting land aside program, it does not deal with the financial sustainability issue. While the bequest or existence value of the tropical forest seems extremely high, its domestic use value is still low and it seems to be the case that the cost of setting aside land would be 
disproportional borne by the local people. Given that it can be argued that the type of biodiversity found at tropical forest in Madagascar is a public international good to be protected for current and future generations, it seems that the international community has to continue to be involved to ascertain the sustainability of protected areas.

\section{References}

Arrow, K., Solow, P., Portney, P. Leamer, E.E., Radner, R., Schuman, K., Report of the NOAA Panel on contingent valuation, NOAA, 1993

Barrett, C.B., Stochastic Food Prices and Slash-and-Burn Agriculture, Environment and Development Economics, vol. 4, no. 2, 1999, pp. 161-176

Barrett, C.B., Dorosh, P., Farmers' welfare and changing food prices: Nonparametric evidence from rice in Madagascar, American Journal of Agricultural Economics, Vol. 78, 1996, pp. 656-669

Blamey, R.K., Bennett, J.W., Morrison, M.D., Yea-Saying in Contingent Valuation Studies, Land Economics, February 1999, 75(1), pp. 126-141

Brand, J., Minten, B., Randrianarisoa, C., Etude d'impact de la deforestation sur la riziculture irriguée, Cahier d'études et de recherches en économie et sciences sociales, No. 6, December 2002, FOFIFA, Antananarivo

Durbin, J., The Potential of Conservation Contracts to Contribute to Biodiversity Conservation in Madagascar, 2001, mimeo

Ferraro, P., Constructing markets for ecosystem services: limitations of development interventions and a role for conservation performance payments, presented at "Constituting the Commons: Crafting Sustainable Commons in the New Millenium", the $8^{\text {th }}$ Conference of the International Association for the Study of Common Property, Bloomington, Indiana, USA, June, 2000

Ferraro, P., Kiss, A., Response, Science, vol. 299, March $28^{\text {th }}, 2003$, pp. 1981-1982

Freudenberger, K., 1999, Flight to the forest: a study of community and household resource management in the commune of Ikongo, Madagascar, LDI, mimeo

Ghimire, K.B., Parks and People: Livelihood Issues in National Parks Management in Thailand and Madagascar, Development and Change, 25(1), 1994, pp. 195-229

Jarosz, L., Defining and explaining tropical deforestation: shifting cultivation and population growth in Colonial Madagascar (1896-1940), Economic Geography, Vol. 69(4), 1993, pp. 366-379

Keck, A., Sharma, N.P., Feder, G., Population Growth, Shifting Cultivation, and Unsustainable Agricultural Development: A Case Study from Madagascar, World Bank Discussion Paper, Africa Technical Department Series, No. 234, World Bank, Washington DC

Kerr, J. Watershed development, environmental services and poverty alleviation in India, World Development, 30(8), 2002, pp. 1387-1400 
Kramer, R., Sharma, N., Shyamsundar, P., Munasinghe, M., Cost and Compensation Issues in Protecting Tropical Rainforests: Case Study in Madagascar, Environment Department Working Paper No. 62, World Bank, Washington DC, 1994

Larson, B.A., Changing the Economics of Environmental Degradation in Madagascar: Lessons from the National Environmental Action Plan Process, World Development, 1994, Vol. 22 (5), pp. 671-689

McNeely, J.A., Miller, K.R., Reid, W.V., Millenmeier, R.A., Weiner, T.B., Conserving the World's Biological Diversity, IUCN-WRI-CI-WWF/US-Word Bank, 1990, 193 p.

Pagiola, S., Bishop, J., Landell-Mills, N., Setting Forest Environmental Services: Market-based Mechanisms for Conservation and Development, 2002, Earthscan, London

Ready, R.C., Navrud, S., Dubourg, W.R., How do respondents with uncertain willingness to pay answer contingent valuation questions, Land Economics, August 2001, vol. 77, no. 3, pp. 315-326

Randrianarisoa, C., Minten, B., Agricultural production, agricultural land and rural poverty in Madagascar, World Bank Technical Paper, Washington DC, forthcoming

Randrianarison, L., Revenu extra-agricole et pauvreté, Paper presented during the conference "Agriculture et pauvreté à Madagascar", FOFIFA/Cornell University, March, 2003, Antananarivo

Shyamsundar, P., Kramer, R.A., Tropical Forest Protection: An Empirical Analysis of the Costs Borne by Local People, Journal of Environmental Economics and Management, Vol. 31, 1996, pp. 129-144

Swart, J.A.A., Will direct payments help biodiversity?, Science, vol. 299, March 28 ${ }^{\text {th }}$, 2003, pp. 1981

Varian, H.R., Microeconomic Analysis, W.W. Norton \& Co., New York, 1992

Wells, M., Brandon, K., Hannah., L., People and Parks: Linking Protected Area Management with Local People, World Bank, World Wildlife Fund and USAID, Washington DC, 1990

White, F., The Vegetation of Africa: A descriptive memoir, UNESCO, Paris, 1993

Whittington, D., Chapter 16: Environmental Issues, in Eds. Grosh, M., Glewwe, P., Designing Household Survey Questionnaires for Developing Countries: Lessons from Ten Years of LSMS Experience, World Bank, 1998 
Table 1: Descriptive statistics of household variables

\begin{tabular}{|c|c|c|c|c|c|c|}
\hline variable & Unit & $\mathbf{N}$ & mean & median & $\min$ & $\max$ \\
\hline size of household & $\begin{array}{l}\text { number of } \\
\text { people }\end{array}$ & 120 & 6.00 & 6 & 2 & 14 \\
\hline education level head of hh & years & 120 & 3.22 & 3 & 0 & 12 \\
\hline gender & $\operatorname{man}=1$ & 120 & 0.92 & 1 & 0 & 1 \\
\hline age & years & 120 & 42.47 & 40 & 18 & 81 \\
\hline lowland & ares & 120 & 73.93 & 40 & 0 & 1500 \\
\hline upland & ares & 120 & 73.52 & 50 & 0 & 1000 \\
\hline savoka & ares & 120 & 59.49 & 40 & 0 & 500 \\
\hline primary forest & ares & 120 & 55.83 & 0 & 0 & 600 \\
\hline zebus & number & 120 & 0.91 & 0 & 0 & 9 \\
\hline zebus de trait & number & 120 & 0.62 & 0 & 0 & 6 \\
\hline income of rice & $1000 \mathrm{Fmg}$ & 120 & 63.90 & 0 & 0 & 1296 \\
\hline income tavy products & $1000 \mathrm{Fmg}$ & 120 & 772.64 & 100 & 0 & 10000 \\
\hline products & $1000 \mathrm{Fmg}$ & 120 & 193.63 & 0 & 0 & 4500 \\
\hline income livestock & $1000 \mathrm{Fmg}$ & 120 & 48.25 & 0 & 0 & 4000 \\
\hline income artisanat & $1000 \mathrm{Fmg}$ & 120 & 2.17 & 0 & 0 & 100 \\
\hline income forest products & $1000 \mathrm{Fmg}$ & 120 & 114.50 & 0 & 0 & 6000 \\
\hline income wage labor & $1000 \mathrm{Fmg}$ & 120 & 99.84 & 0 & 0 & 1260 \\
\hline other income & $1000 \mathrm{Fmg}$ & 120 & 134.17 & 0 & 0 & 3200 \\
\hline total rice production & $\mathrm{kg}$ & 120 & 910.83 & 710 & 80 & 4500 \\
\hline rice production is enough & $\begin{array}{l}\text { yes }=1 \\
\text { number of }\end{array}$ & 120 & 0.24 & 0 & 0 & 1 \\
\hline length of lean period & months & 120 & 3.72 & 3 & 0 & 12 \\
\hline potential access to credit & $1000 \mathrm{Fmg}$ & 120 & 414.21 & 100 & 0 & 16000 \\
\hline
\end{tabular}


Table 2: Descriptive statistics tavy practices

\begin{tabular}{llrrrrr}
\hline variable & Unit & $\mathbf{N}$ & mean & median & min & max \\
\hline importance tavy in rice production & $\%$ & 120 & 24.78 & 0 & 0 & 100 \\
reasons for area in tavy & & & & & & \\
need food & yes=1 & 120 & 0.58 & 1 & 0 & 1 \\
need for cash & yes=1 & 120 & 0.18 & 0 & 0 & 1 \\
area available in the forest & yes=1 & 120 & 0.09 & 0 & 0 & 1 \\
decision of the clan & yes=1 & 120 & 0.12 & 0 & 0 & 1 \\
other reason & yes=1 & 120 & 0.04 & 0 & 0 & 1 \\
& & & & & & \\
willingness to abandon tavy for compensation & yes=1 & 120 & 0.93 & 1 & 0 & 1 \\
willingness to abandon forest use for & & & & & & \\
compensation & yes=1 & 114 & 0.85 & 1 & 0 & 1 \\
\hline proportion of farmers that cultivate & & & & & & \\
rice & ratio & 120 & 1.00 & 1 & 1 & 1 \\
cassava & ratio & 120 & 0.85 & 1 & 0 & 1 \\
mais & ratio & 120 & 0.08 & 0 & 0 & 1 \\
vanilla & ratio & 120 & 0.34 & 0 & 0 & 1 \\
coffee & ratio & 120 & 0.28 & 0 & 0 & 1 \\
cloves & ratio & 120 & 0.53 & 1 & 0 & 1 \\
ananas & ratio & 120 & 0.18 & 0 & 0 & 1 \\
litchis & ratio & 120 & 0.28 & 0 & 0 & 1 \\
rice production per household & & & & & & \\
cassava production per household & $\mathrm{kg}$ & 120 & 925.23 & 720 & 80 & 4500 \\
maize production per household & $\mathrm{kg}$ & 120 & 1.58 & 0 & 0 & 120 \\
vanilla production per household & $\mathrm{kg}$ & 120 & 3.89 & 0 & 0 & 120 \\
coffee production per household & $\mathrm{kg}$ & 120 & 5.57 & 0 & 0 & 70 \\
cloves production per household & $\mathrm{kg}$ & 120 & 6.46 & 0 & 0 & 210 \\
ananas production per household & $\mathrm{kg}$ & 120 & 22.49 & 0 & 0 & 300 \\
litchis production per household & $\mathrm{kg}$ & 120 & 18.25 & 0 & 0 & 500 \\
\hline & $\mathrm{kg}$ & 120 & 51.33 & 0 & 0 & 840 \\
\hline
\end{tabular}


Table 3: Willingness to accept compensation to abandon tavy and forest use

\begin{tabular}{llrr}
\hline & & Number of sobika & \\
\hline Tavy & & & \\
Accept for sure & Mean & 64 & 118 \\
& Median & 46 & 85 \\
Refuse for sure & & 51 & 94 \\
& Mean & 32 & 59 \\
\hline Forest use & Median & & \\
Accept for sure & & & \\
& Mean & 148 & 273 \\
Refuse for sure & Median & 177 \\
& & & \\
& Mean & 132 & 244 \\
& Median 1 sobika=12 kg of paddy rice, valued at 1.85\$ & 144 \\
\hline
\end{tabular}


Table 4: Willingness to accept to abandon tavy practice

\begin{tabular}{|c|c|c|c|c|c|c|c|}
\hline & & \multicolumn{6}{|c|}{ Dependent variable (log(amount)) } \\
\hline & & \multicolumn{3}{|c|}{ Level accepted for sure } & \multicolumn{3}{|c|}{ Level refused for sure } \\
\hline & & \multicolumn{2}{|c|}{ Number of obs $=$} & 111 & \multicolumn{3}{|c|}{111} \\
\hline & & \multicolumn{2}{|c|}{$F(8,102)=$} & 1.98 & \multicolumn{3}{|r|}{2.24} \\
\hline & & \multicolumn{2}{|c|}{ Prob $>F=$} & 0.0558 & \multicolumn{3}{|r|}{0.0186} \\
\hline & & \multicolumn{2}{|c|}{ R-squared= } & 0.162 & \multicolumn{3}{|r|}{0.1871} \\
\hline & & \multicolumn{2}{|c|}{ Root MSE= } & 0.972 & \multicolumn{3}{|r|}{1.0373} \\
\hline Determinants & Unit & Coef. & $\mathrm{t}$ & $P>|t|$ & Coef. & $\mathrm{t}$ & $P>|t|$ \\
\hline length of lean period & months & -0.070 & -1.810 & 0.073 & -0.083 & -2.080 & 0.040 \\
\hline size of household & $\log ($ members $)$ & 0.149 & 0.470 & 0.637 & -0.110 & -0.400 & 0.691 \\
\hline education level head of hh & $\log ($ years $)$ & 0.237 & 1.430 & 0.156 & 0.296 & 1.760 & 0.082 \\
\hline age & $\log ($ years) & 0.173 & 0.380 & 0.708 & 0.262 & 0.660 & 0.508 \\
\hline lowland area & $\log ($ ares) & -0.072 & -0.860 & 0.390 & -0.124 & -1.640 & 0.105 \\
\hline upland area & $\log ($ ares) & 0.172 & 3.130 & 0.002 & 0.200 & 3.480 & 0.001 \\
\hline forest area & $\log ($ ares $)$ & 0.018 & 0.380 & 0.704 & 0.035 & 0.720 & 0.474 \\
\hline savoka area & $\log ($ ares $)$ & 0.038 & 0.830 & 0.407 & 0.057 & 1.200 & 0.232 \\
\hline intercept & & 2.413 & 1.520 & 0.131 & 2.108 & 1.430 & 0.156 \\
\hline
\end{tabular}


Table 5: Willingness to accept to abandon forest use

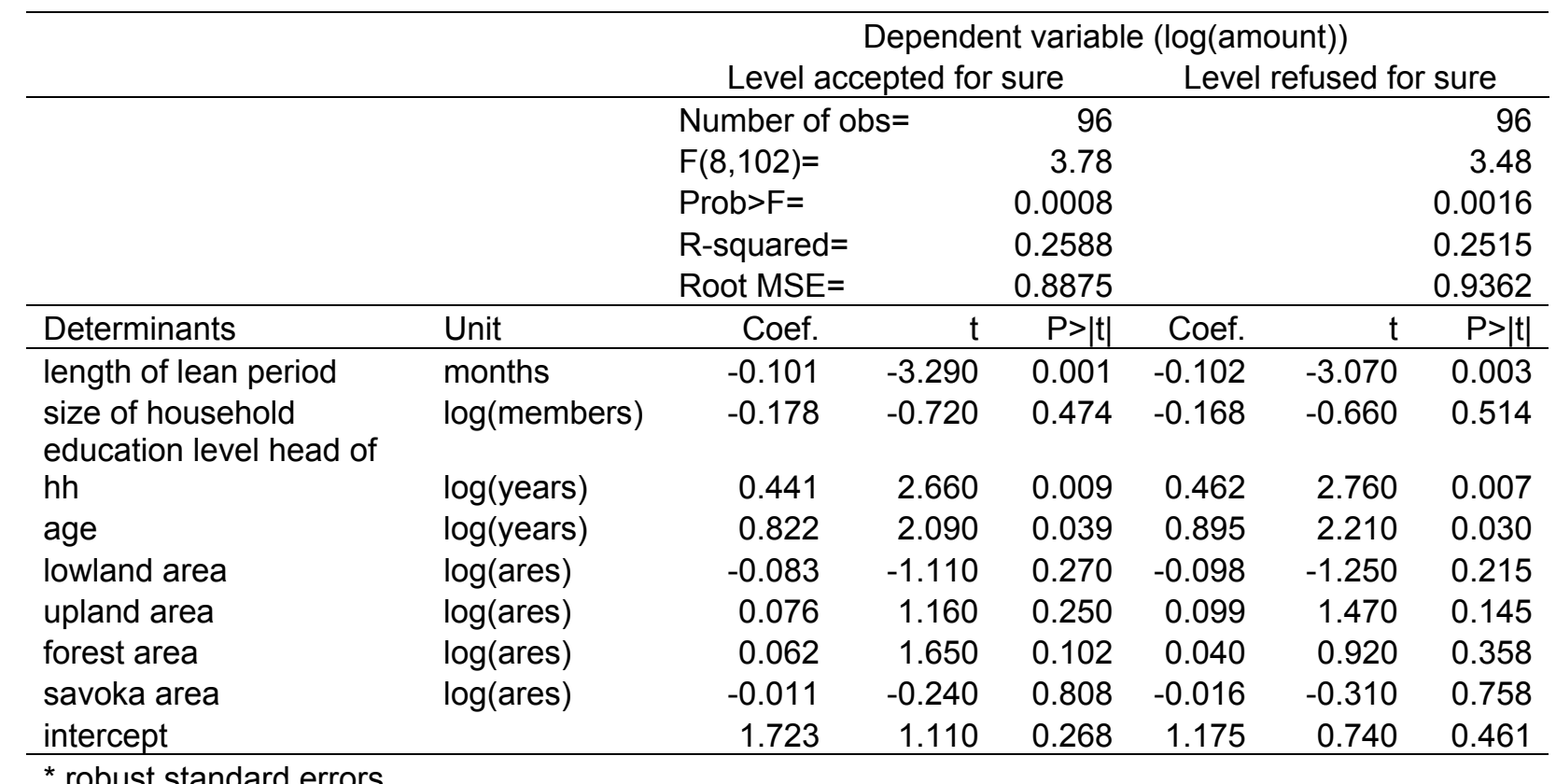




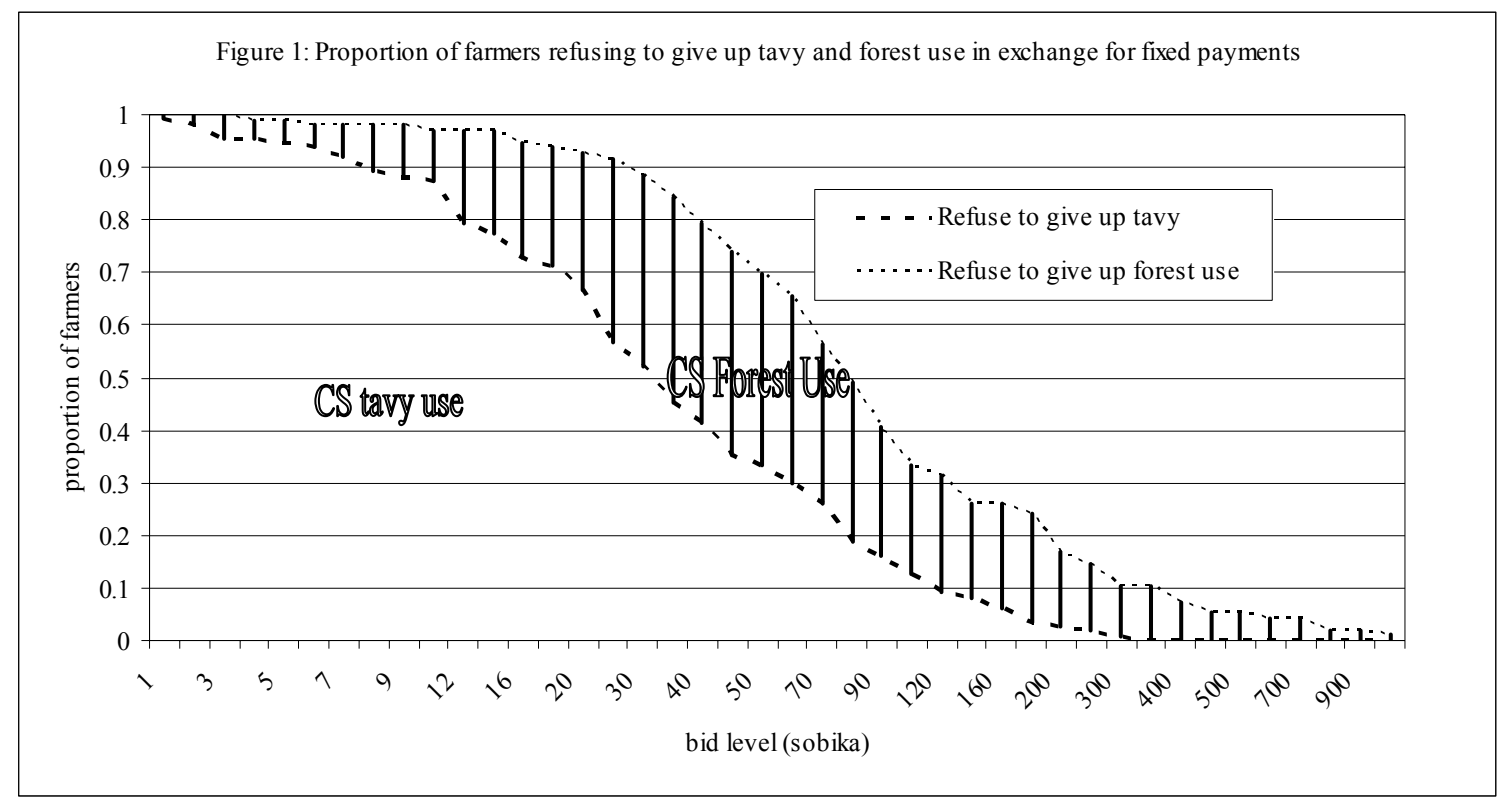




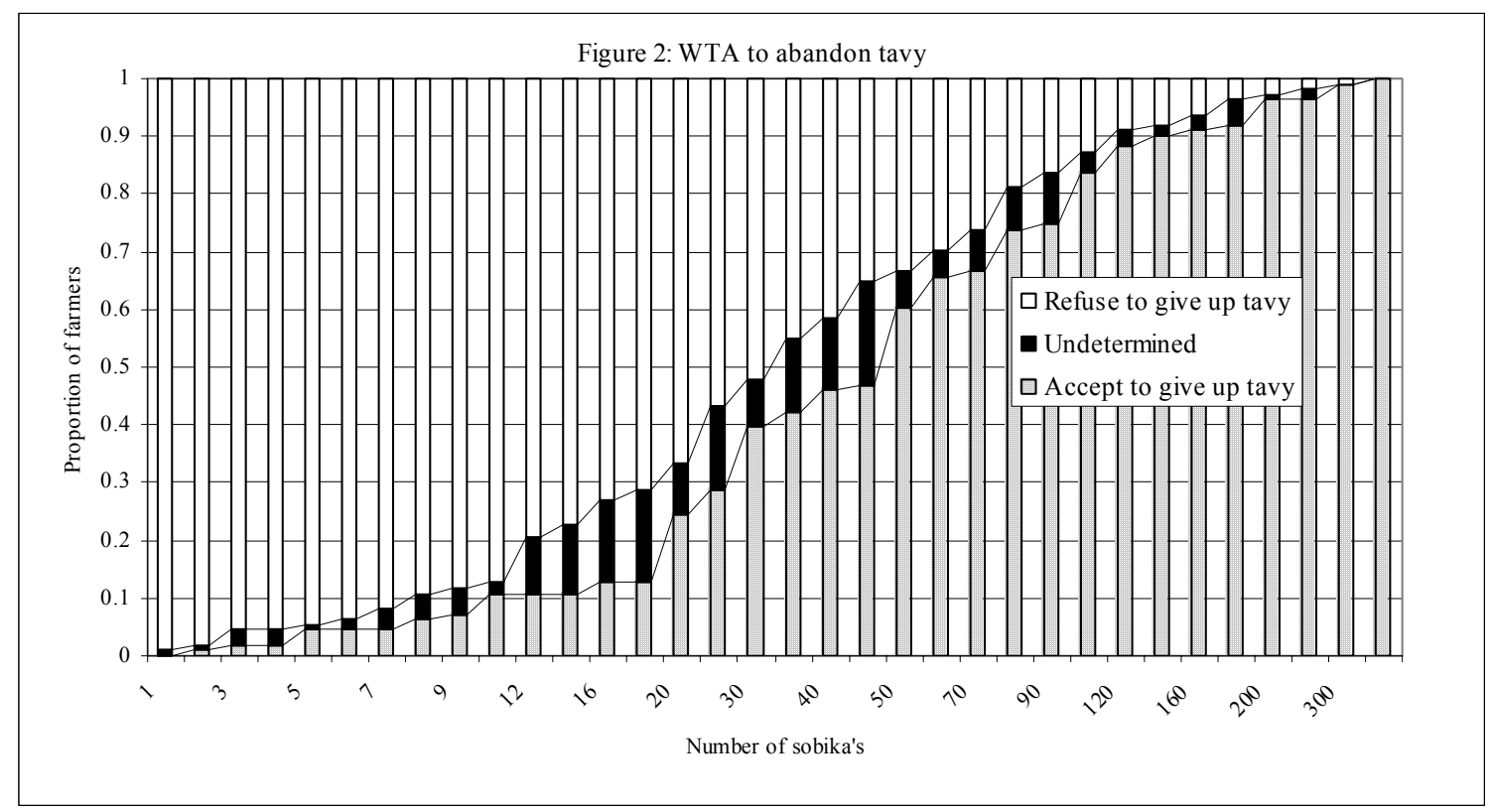




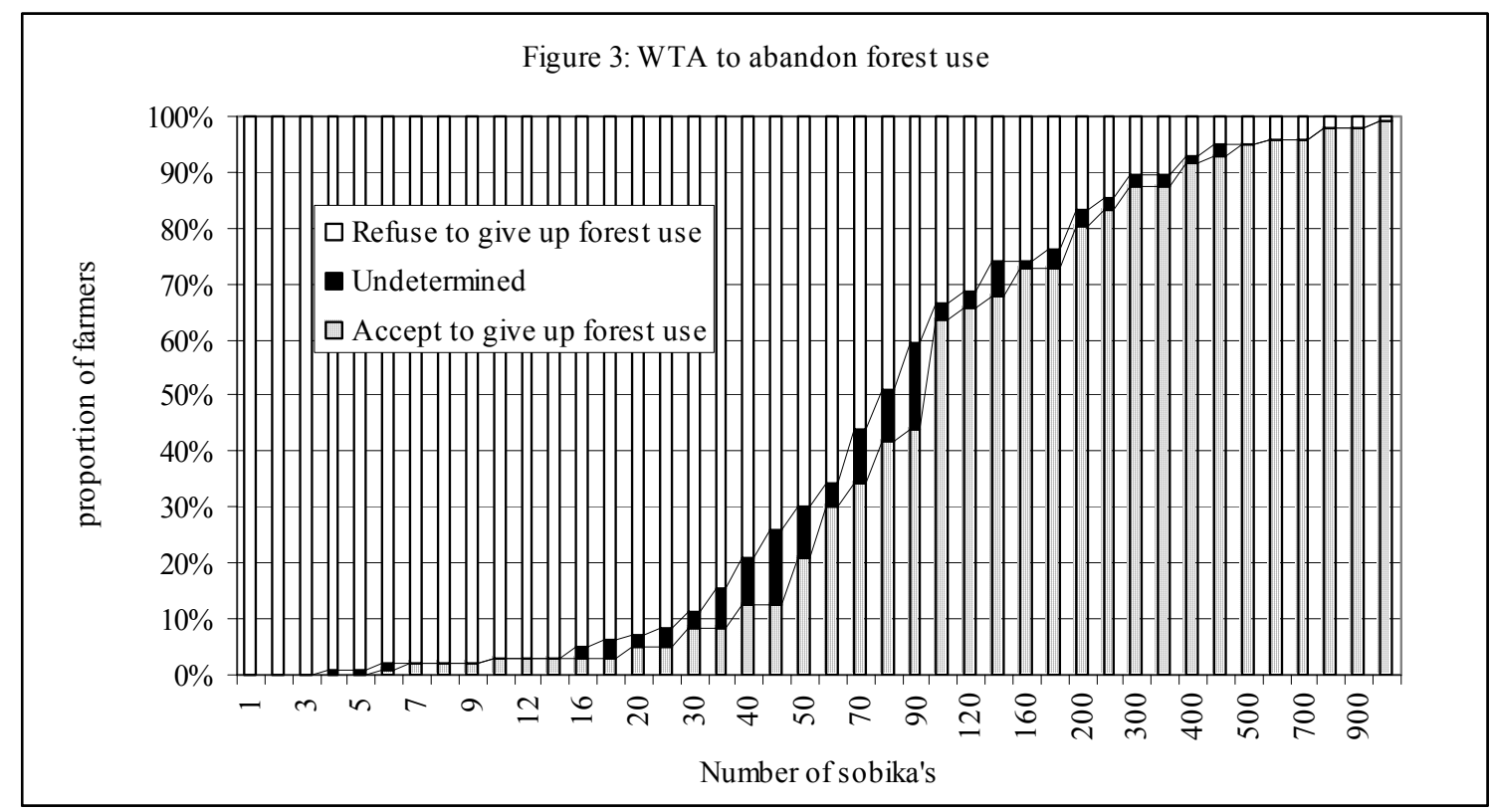

